Journal of Agricultural Sciences
(Tarim Bilimleri Dergisi)

\title{
Reproductive Characteristics of Chios Ram Lambs During the First Year of Life in Rural Farm Conditions
}

\author{
Funda ERDOĞAN ATAÇa (iD), Mustafa KAYMAKÇI ${ }^{\mathrm{a}}$ (iD \\ ${ }^{a}$ Department of Animal Science, Faculty of Agriculture, University of Ege, P.O. Box 35100, Izmir, TURKEY \\ ARTICLE INFO \\ Research Article \\ Corresponding Author: Funda ERDOĞAN ATAÇ, E-mail: funda.erdogan.atac@ege.edu.tr \\ Received: 26 March 2019 / Revised: 02 December 2019 / Accepted: 12 December 2019 / Online: 18 January 2021
}

\section{ABSTRACT}

This study was conducted to determine some of the reproductive characteristics of young Chios rams. For the purposes of this study, the data was obtained and used from 30 Chios ram lambs born in 2009 between the ages of 90-360 days. The minimum and maximum values of the testicular diameter $(\mathrm{cm})$ and length $(\mathrm{cm})$, scrotal circumference $(\mathrm{cm})$, scrotal length $(\mathrm{cm})$, testicular volume $\left(\mathrm{cm}^{3}\right)$ of the Chios ram lambs were 1.59-7.30, 3.05-14.23, 12.00-37.50, 7.00-32.00, 17.39-771.44, respectively. Phenotypic correlations between all testis characteristics were found to be statistically significant $(\mathrm{P}<0.01)$. The average testosterone hormone in Chios ram lambs was observed to be $7.05 \pm 0.31$ $\mathrm{ng} \mathrm{x} \mathrm{ml} \mathrm{m}^{-1}$. The ejaculate volume, sperm density, progressive motility ratio, immotility ratio, general averages of the ratio of dead spermatozoa and mass movement- consistency of sperm values were examined on sperm of ram lambs at 240, 270, 300 and 330 age of days. Mean values of these traits were obtained as $1.37 \mathrm{~mL} ; 3.95 \times 10^{9} \mathrm{~mL}^{-1}, 82.20 \%, 7.07 \%, 10.73$ $\%$ and 4.40-4.09, respectively. Moreover, progressive motility, the effect of live weight and age in other sperm characteristics was found statistically nonsignificant $(\mathrm{P}>0.05)$. The testicular diameter and volume, scrotal circumference and scrotal length enlarged related with positively the rate of the sperm motility. As a result, estimating the rate of live spermatozoa of the ram lambs by taking morphological measurements at an early age can be useful. Therefore, this information was vulnerable in indirect selection programs.

Keywords: Chios; Ram Lamb; Testicular Characteristics; Testosterone Hormone; Sperm Characteristics

(C) Ankara University, Faculty of Agriculture

\section{Introduction}

One of the most important indicators of successful livestock is reproductive performance. Good reproductive management of domestic animals requires detailed information about the onset of puberty and sexual maturity (Ake-Lopez et al. 2016; AlKawmani et al. 2018). This is also used as important criteria for the selection of ram lambs in a breed (Kridli \& Al-Yacoub 2006; Hassanin et al. 2013). In addition, although most sheep breeds are season-dependent, it is known that puberty varies between one breed to another in rams (Hassanin et al. 2013). The capacity of reproductive yields for male animals can be predicted in short time by using some measurements and this information might be used to reveal for reproductive fertility of relative females by indirect selection (Odabaşığlu et al. 1992; Aygün \& Karaca 1995; Taşkın \& Kaymakçı 1996; Rege et al. 2000; Toe et al. 2000; Kaymakçı 2016). In the selection of superior rams in terms of fertility, the use of certain properties alone or in combination and the resulting effect levels are important (Kridli \& Said 1999; Price et al. 2000). The efficiency of selection programs depends on these characteristics.

Chios sheep is one of the most important native and prolific breeds in Turkey. In this study, variables related to reproductive characteristics of Chios rams during the first year of life have been revealed in rural farm conditions. Also, investigation of the relationship between testis characteristics, serum testosterone level, sperm yield, semen quality and studied reproductive characteristics of Chios ram lambs were aimed. This research, moreover, can help the early and correct selection of Chios ram lamb and will provide important scientific information in the literature.

\section{Material and Methods}

\subsection{Animal material}

A total of 30 Chios ram lambs were used as an animal material for the study. Lambs were raised with their mothers until the 
weaning period, and they were separated from their mothers after 3 months of age. The lambs were randomly selected from those with a maximum age difference of 15 days, 2-years old mother, and twin-born. They were raised using natural methods until weaning age. The animals were fed according to the existing feeding program. Data were obtained monthly from lambs between 90 - 360 days of age.

\subsection{Examined characteristics}

In order to determine the testis characteristics, the diameter and length were measured with an electronic caliper, testicular volume was calculated by 0.0396 x Mean Testicular Length $\mathrm{x}$ (Scrotal Circumference) ${ }^{2}$, scrotal circumference and scrotal length were measured using a flexible tape (Kırk 2001; Yılmaz \& Cengiz 2006; Kaymakç1 2016). Blood samples were collected monthly from the jugular vein of each ram in $10 \mathrm{~mL}$ heparinized vacutainer tubes, between the ages of 3 and 12 months at $8.30-10.00$ am. Bloods were centrifuged at $5000 \mathrm{rpm}$ for 10 minutes in a cooled centrifuge set at $+4{ }^{\circ} \mathrm{C}$. Serum samples for each ram lamb were collected in $2 \mathrm{~mL}$ eppendorf tubes and stored in the freezer at $-20^{\circ} \mathrm{C}$ until hormone was determined (Tietz 1987). Testosterone hormone determination, using Testosterone Sheep Kit, was made by Radioimmunoassay (RIA) method (Delgadillo et al. 1991; Wilson 1999; Y1lmaz 1999; Cusabio 2011). The semen characteristics of the animals were determined with taking the average of monthly measurements by artificial vagina. The amount of sperm $(\mathrm{mL})$, consistency of sperm (0-5) and sperm mass movement (0-5) were examined (Tekin 1990; Taşkın 1995). A chemical preparation was used as a diluent (Minitube 2013). Sperm vision has proven to be reliable in the field and has been developed for the purpose of determining the spermatological properties with practical and recent technology. Sperm vision can be analyzed with a computer-connected microscope, was used to calculate total live, progressive motility and immotility ratios (\%) (Tsakmakidis 2010; Minitube 2013). Sperm density (109 $\mathrm{mL}^{-1}$ ) was measured with the photometer.

\subsection{Analysis of data}

In the study, normality test was applied to the testosterone hormone, testis and sperm characteristics. As a result of this test, it was determined that the data of testosterone hormone was not valid to normal distribution assumptions and square root transformation was applied. The effect of age on testosterone hormone, testis and semen properties was determined by covariance analysis (Model 1) (Düzgüneş et al. 1987; İkiz et al. 1996). The least square means of age effect for all levels were estimated and difference of the means were compared by Duncan multiple comparison test (Düzgüneş et al. 1987). In addition, the correlations between testosterone hormone, testis and sperm characteristics were investigated. Phenotypic correlation coefficients and their significance levels were discussed. However, the tendency of testosterone hormone, testis and sperm characteristics according to age and live weights were modelled by regression analysis (Düzgüneş et al. 1987; İkiz et al. 1996) (Model 2). Ordinal logistic regression analysis was performed for semen movement and sperm consistency (İkiz et al. 1996). All statistics were performed by using JMP 5.0.1.2 and IBM SPSS 25v statistical package programs (JMP 2003; IBM SPSS 2017).

$\mathrm{Y}_{\mathrm{ij}}=\mu+\mathrm{a}_{\mathrm{i}}+\mathrm{b}_{1}\left(\mathrm{X}_{\mathrm{ij}}-\bar{x}\right)+\mathrm{e}_{\mathrm{ij}}$

Where the parameters denote; $\mathrm{Y}_{\mathrm{ij}}$ : Characteristics of testis, sperm or testosterone hormone level, $\mu$ : Population mean, $\mathrm{a}_{\mathrm{i}}$ : $\mathrm{i}$. age effect, $b_{1}$ : The regression coefficient related with live weight, $\mathrm{X}_{\mathrm{ij}}$ : The covariate at $\mathrm{i}$. age and $\mathrm{j}$. ram lamb, $\bar{x}: \mathrm{Mean}$ live weight of ram lamb and $\mathrm{e}_{\mathrm{ij}}$ : Random error term, respectively.

$Y_{i j k}=b_{0}+b_{i} X_{i}+b_{j} X_{j}+e_{i j k}$

Where the parameters denote; $\mathrm{Y}_{\mathrm{ijk}}$ : Characteristics of testis or sperm, $\mathrm{b}_{0}$ : The constant term of $\mathrm{Y}$ axis, $\mathrm{b}_{\mathrm{i}}$ : The regression coefficient for live weight of ram lamb, $b_{j}$ : The regression coefficient for age, $X_{\mathrm{i}}$ : Live weight of ram lamb, $\mathrm{X}_{\mathrm{j}}$ : The age effect and $\mathrm{e}_{\mathrm{ijk}}$ : Random error term, respectively.

\section{Results and Discussion}

The least square means of the testis characteristics of Chios ram lambs are given in Table 1. It was observed that testicular diameter and length increased continuously in the 90-360 days of age groups. The age effect on testicular diameter, length and volume were found statistically significant $(\mathrm{P}<0.01)$, however the age effect was not varied after the age of 210 days. Moore $\&$ Sanford (1987) also found similar results in their study of Suffolk and $1 / 2$ Dorset x $1 / 4$ Leicester x $1 / 4$ Suffolk crossbreed rams. Scrotal length changed significantly at 90, 210 and 360 days; it steadily increased until August and then rapidly declined. It was thought that this difference appeared with live weight and age and then was affected by temperature and season in other periods. Kaymakçı et al. (1988) found that the impact of age on the scrotal circumference was non-significant (P>0.05), although Moraes et al. (1992), Odabaşığlu et al. (1992), Aygün \& Karaca (1995) reported that the effect of live weight was significant (P<0.05). Age and live weight had significant effect on all testis characteristics $(\mathrm{P}<0.01)$. Some researchers have also reported similar findings (Nowakowski \& Cwikla 1994; Aygün \& Karaca 1995; Taşkın \& Kaymakçı 1996; Salhaba et al. 2001; Özdemir \& Altın 2002; Y1lmaz \& Aygün 2002; İnce \& Karaca 2009). 
Table 1- Least square means and standard deviations of testis characteristics in Chios ram lambs and regression analysis results

\begin{tabular}{lcccccc}
\hline & $T D, c m$ & $T L, c m$ & $S C, c m$ & $S L, c m$ & $T V, c m^{3}$ \\
\hline Effect & $\mathrm{n}$ & $\bar{x} \pm S_{\bar{x}}$ & $\bar{x} \pm S_{\bar{x}}$ & $\bar{x} \pm S_{\bar{x}}$ & $\bar{x} \pm S_{\bar{x}}$ & $\begin{array}{c}\bar{x} \pm S_{\bar{x}} \\
\text { Overall Mean }\end{array}$ \\
\hline Age (Day) & 298 & $4.94 \pm 0.09$ & $9.73 \pm 0.16$ & $28.88 \pm 0.41$ & $21.34 \pm 0.35$ & $377.01 \pm 11.96$ \\
\hline 90 & 30 & $3.48 \pm 0.17^{\mathrm{d}}$ & $6.51 \pm 0,25^{\mathrm{e}}$ & $21.35 \pm 0.74^{\mathrm{f}}$ & $15.89 \pm 0.59^{\mathrm{e}}$ & $246.05 \pm 21.03^{\mathrm{d}}$ \\
120 & 30 & $3.90 \pm 0.13^{\mathrm{c}}$ & $7.80 \pm 0.21^{\mathrm{d}}$ & $25.04 \pm 0.65^{\mathrm{e}}$ & $18.18 \pm 0.51^{\mathrm{cd}}$ & $268.78 \pm 18.24^{\mathrm{d}}$ \\
150 & 30 & $4.24 \pm 0.09^{\mathrm{c}}$ & $8.78 \pm 0.17^{\mathrm{c}}$ & $27.95 \pm 0.49^{\mathrm{d}}$ & $18.07 \pm 0.39^{\mathrm{d}}$ & $298.65 \pm 13.89^{\mathrm{cd}}$ \\
180 & 30 & $4.67 \pm 0.09^{\mathrm{b}}$ & $9.68 \pm 0.15^{\mathrm{b}}$ & $29.82 \pm 0.45^{\mathrm{cd}}$ & $19.87 \pm 0.35^{\mathrm{c}}$ & $349.79 \pm 12.64^{\mathrm{bc}}$ \\
210 & 30 & $5.22 \pm 0.08^{\mathrm{a}}$ & $10.39 \pm 0.14^{\mathrm{a}}$ & $31.83 \pm 0.43^{\mathrm{ab}}$ & $24.33 \pm 0.33^{\mathrm{ab}}$ & $419.55 \pm 12.04^{\mathrm{a}}$ \\
240 & 30 & $5.47 \pm 0.08^{\mathrm{a}}$ & $10.67 \pm 0.15^{\mathrm{a}}$ & $32.28 \pm 0.43^{\mathrm{a}}$ & $25.17 \pm 0.34^{\mathrm{a}}$ & $452.13 \pm 12.22^{\mathrm{a}}$ \\
270 & 30 & $5.56 \pm 0.09^{\mathrm{a}}$ & $10.74 \pm 0.16^{\mathrm{a}}$ & $31.64 \pm 0.47^{\mathrm{abc}}$ & $25.04 \pm 0.37^{\mathrm{a}}$ & $450.44 \pm 13.23^{\mathrm{a}}$ \\
300 & 30 & $5.59 \pm 0.10^{\mathrm{a}}$ & $10.79 \pm 0.18^{\mathrm{a}}$ & $30.89 \pm 0.52^{\mathrm{abc}}$ & $23.82 \pm 0.41^{\mathrm{ab}}$ & $445.06 \pm 14.77^{\mathrm{a}}$ \\
330 & 29 & $5.64 \pm 0.12^{\mathrm{a}}$ & $10.96 \pm 0.20^{\mathrm{a}}$ & $29.83 \pm 0.60^{\mathrm{bcd}}$ & $22.43 \pm 0.47^{\mathrm{b}}$ & $436.00 \pm 16.99^{\mathrm{a}}$ \\
360 & 29 & $5.64 \pm 0.13^{\mathrm{a}}$ & $11.03 \pm 0.24^{\mathrm{a}}$ & $28.19 \pm 0.70^{\mathrm{de}}$ & $20.61 \pm 0.55^{\mathrm{c}}$ & $406.55 \pm 19.21^{\mathrm{ab}}$ \\
\hline Regression & $($ linear) & & & & & \\
\hline Live Weight & & $0.04 \pm 0.001^{* *}$ & $0.08 \pm 0.007^{* *}$ & $0.24 \pm 0.03^{* *}$ & $0.19 \pm 0.02^{* *}$ & $7.82 \pm 0.65^{* *}$ \\
\hline
\end{tabular}

**a,b,c,d,e,f; Mean with different letters in the same column indicate significant differences (P<0.01), TD: Testicular Diameter, TL: Testicular Length, SC: Scrotal Circumference, SL: Scrotal Length, TV: Testicular Volume

The regression equations related to testis characteristics of Chios ram lambs are shown in Table 2. Since the age and live weight in ram lambs led to high variability in testis characteristics, all testis characteristics in the study were affected by age and live weight. This finding was consistent with that reported by Salhaba et al. (2001) and Al-Kawmani et al. (2018). Testicular size may be useful as a selection criterion to increase the reproductive capacity of male lambs (Toe et al. 2000; Hassanin et al. 2013; Ake-Lopez et al. 2016; Al-Kawmani et al. 2018). When the change of testosterone hormone level of Chios ram lambs was examined by age, it was observed that testosterone levels started to decrease in spring but raised back to the initial levels until the end of summer and decreased again at the end of August. However, the effect of age and live weight on testosterone hormone was not statistically significant $(\mathrm{P}>0.05)$ therefore any the table information was not given. The total secretion of testosterone was determined as $7.05 \pm 0.31 \mathrm{ng} \mathrm{x} \mathrm{mL}^{-1}$ during the all months. This value was lower than values reported in Ile de France, Herdwick, Norfolk, Shetland and Wildshire breeds (Gonzalez et al. 1988; Lincoln et al. 1990), and higher than Canadian, Outaouais, Rideau and Finnish Landrace, İvesi, Muflon and Soay x Merino, Akkaraman, Konya Merino, Iran Moghani breeds (Lincoln et al. 1990; Langford et al. 1998; Gündoğan 1999; Kaya et al. 1999; Kırk 2001; Zamiria et al. 2010). Nevertheless, this value agreed with the reports of Lincoln et al. (1990) on Blackface and Portland, Ismaeel (2018) on Nuaimie and Aguirre et al. (2007) on Pelibuey rams. In this study, the increase in the amount of testosterone with the sexual maturity (Al-Kawmani et al. 2018), but the decrease for the amount of testosterone at the end of mating season and by cooling weather was found to be consistent with Courot \& Ortavant (1981) and Gündoğan \& Demirci (2003).

Table 2- Regression equations related with testis characteristics on Chios ram lambs

\begin{tabular}{lcccc}
\hline Parameter & Regression Equations & $S_{\bar{x}}$ & $F$ & $R^{2}$ \\
\hline Testicular diameter & $\mathrm{Y}=1.003+0.007$ age+0.050 LW & 0.09 & $<0.001$ & $0.88^{*}$ \\
Testicular length & $\mathrm{Y}=2.586+0.012$ age+0.098 LW & 0.17 & $<0.001$ & $0.88^{*}$ \\
Scrotal circumference & $\mathrm{Y}=11.802+0.009$ age+0.327 LW & 0.59 & $<0.001$ & $0.76^{*}$ \\
Scrotal length & $\mathrm{Y}=6.737+0.018$ age+0.231 LW & 0.51 & $<0.001$ & $0.76^{*}$ \\
Testicular volume & $\mathrm{Y}=-155.423+0.615$ age+8.573 LW & 13.14 & $<0.001$ & $0.86^{*}$ \\
\hline
\end{tabular}

$* \mathrm{P}<0.05$, LW: Live Weight

The least square means for the sperm characteristics of Chios ram lambs are given on Table 3. The volume of ejaculate measured in Chios ram lambs was consistent with Iranian Moghani, Corriedale, Akkaraman and Çine Çaparı breeds (Gülyüz \& Y1ld1z 1995; İnce \& Karaca 2009; Zamiria et al. 2010). However, it was lower than the values reported for Karya (İnce \& Karaca 2009), Santa Inês (Souza et al. 2010), and Chios and Friesian breeds (Karagiannidis et al. 2000). The sperm density was similar to rams of Pelibuey, Norduz, Karayaka, Konya Merino, Dağlıç, Akkaraman breeds (Gündoğan et al. 1997; Kaya et al. 1999; Y1lmaz \& Cengiz 2006; Aguirre et al. 2007; Gündoğan 2007; Kulaksız et al. 2010). In terms of sperm motility ratio for German Black Head, Awl, Iranian Moghani, Hamdane, Karayaka, Akkaraman breeds (Soylu et al. 1991; Karaca et al. 1998; Gündoğan et al. 2002; Sönmez \& Demirci 2003; Kulaksız et al. 2010; Zamiria et al. 2010) and the immotility ratio (Aksoy et al. 1994; Karakuş \& Cengiz 2007) was consistent with domestic, local and culture breeds such as Akkaraman and Karakaş breeds. The ratio of dead spermatozoa in Chios ram lambs were lower than the levels reported for Çine Çaparı (İnce \& Karaca 2009), Karayaka (Kulaksız et al. 2010), and Karya and Chios breeds (Yılmaz \& Karaca 2004); and higher than Karakaş, Norduz and Hamdane breeds (Karaca et al. 1998; Karakuş \& Cengiz 2007). The ejaculate volume, sperm density, and sperm motility values obtained in this study were higher than those of prolific breeds such as Chios, Barki, Dorset Down, German Black Head, Border 
Leicester, Rambouillet and Romanov (Soylu et al. 1991; Gülyüz \& Y1ldı, 1995; Martin et al. 1999; Taha et al. 2000; Aguirre et al. 2007; Gündoğan 2007).

Table 3- Least square means and standard deviations of some sperm characteristics in Chios ram lambs and regression analysis results

\begin{tabular}{ccccccc}
\hline Traits & & $E V, m L$ & $S D \times 10^{9} m L^{-1}$ & $P M R, \%$ & $I M R, \%$ & $D S O, \%$ \\
\hline Effect & $\mathrm{n}$ & $\bar{x} \pm S_{\bar{x}}$ & $\bar{x} \pm S_{\bar{x}}$ & $\bar{x} \pm S_{\bar{x}}$ & $\bar{x} \pm S_{\bar{x}}$ & $\bar{x} \pm S_{\bar{x}}$ \\
Overall Mean & 35 & $1.37 \pm 0.05$ & $3.95 \pm 0.18$ & $82.20 \pm 0.99$ & $7.07 \pm 0.58$ & $10.73 \pm 0.55$ \\
\hline Age (Day) & & & & & \\
\hline 240 & 3 & $1.44 \pm 0.23$ & $4.89 \pm 0.71$ & $81.32 \pm 3.75$ & $9.38 \pm 2.14$ & $9.29 \pm 2.23$ \\
270 & 7 & $1.21 \pm 0.13$ & $3.95 \pm 0.41$ & $82.81 \pm 2.13$ & $6.30 \pm 1.22$ & $10.86 \pm 1.27$ \\
300 & 12 & $1.47 \pm 0.09$ & $4.13 \pm 0.29$ & $84.80 \pm 150$ & $5.31 \pm 0.86$ & $9.88 \pm 0.89$ \\
330 & 13 & $1.36 \pm 0.11$ & $3.56 \pm 0.34$ & $79.68 \pm 1.77$ & $8.57 \pm 1.01$ & $11.77 \pm 1.05$ \\
\hline Regression & (linear) & \multicolumn{5}{c}{} \\
\hline Live Weight & & $-0.01 \pm 0.01$ & $-0.03 \pm 0.04$ & $0.51 \pm 0.22^{*}$ & $-0.23 \pm 0.12$ & $-0.28 \pm 0.13^{*}$ \\
\hline
\end{tabular}

*P<0.05, EV: Ejaculate Volume, SD: Sperm Density, PMR: Progressive Motility Ratio, IMR: Immotility Ratio, DSO: Dead Spermatozoa Ratio

While the effect of age on spermatological characteristics was not significant, the effect of live weight on the ratio of motile spermatozoa and dead spermatozoa ratio was significant $(\mathrm{P}<0.05)$. Salhaba et al. (2003) obtained that age did not have a significant effect on spermatozoa viability between 11-20 months of age. According to Gündoğan et al. (2003b), the change of sperm density with age was not significant, but Souza et al. (2010) found that it was important. Several studies on rams emphasized that the change in ejaculate volume with age was significant $(\mathrm{P}<0.05)$ (Rege et al. 2000; Gündoğan et al. 2003a; Salhaba et al. 2003). Öztürkler et al. (1997) found that photoperiodic effect greatly changed the sperm characteristics, Maxwell (1986) and Y1lmaz \& Karaca (2004) also indicated that the quality of sperm was better during the mating season. As expected, there was an increase in the ratio of motile spermatozoa with age, and a decrease in abnormal spermatozoa rates when sperm was taken on the $240^{\text {th }}$ and $300^{\text {th }}$ days. Similar results have been observed in other studies (Alexopoulos et al. 1991; Taşkın 1995; Kırk 2001; Gündoğan et al. 2003a, Souza et al. 2010). However, these increases and decreases in the rate of spermatozoa were not statistically significant in these studies. Salhaba et al. (2003) also reported that the live sperm ratio was not affected by age and season. Nevertheless, Dufour et al. (1984) found that the highest rate of live spermatozoa was in October to November, and Ince \& Karaca (2009) found the highest rate of spermatozoa in the autumn and the lowest in the summer. These results were consistent with the findings in this study. It was determined that the sperm of Chios lambs had the same mass movement and cream color on the analysis days (Table 4).

Table 4- Descriptive statistics of sperm mass movement and consistency of sperm in Chios ram lambs

\begin{tabular}{cccc}
\hline Traits & & Mass Movement & Consistency of Sperm \\
\hline Effect & $\mathrm{n}$ & $\bar{x} \pm S_{\bar{x}}$ & $\bar{x} \pm S_{\bar{x}}$ \\
Overall Mean & 35 & $4.40 \pm 0.07$ & $4.09 \pm 0.08$ \\
\hline Age (Day) & & & \\
\hline 240 & 3 & $4.17 \pm 0.44$ & $3.50 \pm 0.50$ \\
270 & 7 & $4.36 \pm 1.57$ & $4.07 \pm 0.06$ \\
300 & 12 & $4.53 \pm 0.88$ & $4.29 \pm 0.13$ \\
330 & 13 & $4.36 \pm 0.09$ & $4.06 \pm 0.13$ \\
\hline
\end{tabular}

For Chios ram lambs, the live weight and age were found to be nonsignificant $(\mathrm{P}>0.05)$ in predicting sperm characteristics (Table 5), but it had a significant effect on the ratio of live spermatozoa in one direction $(\mathrm{P}<0.05)$. Apart from age and live weight, other environmental and some genetic factors are thought to play a role on these characteristics.

Table 5- Regression equations related with sperm characteristics in Chios ram lambs

\begin{tabular}{llccc}
\hline Parameter & Regression Equations & $S_{\bar{x}}$ & $\mathrm{~F}$ & $\mathrm{R}^{2}$ \\
\hline Ejaculate volume & $\mathrm{Y}=1.805+0.001$ age-0.011 LW & 0.62 & 0.65 & 0,03 \\
Sperm density & $\mathrm{Y}=9.532-0.010$ age-0.039 LW & 1.86 & 0.06 & 0,12 \\
Progressive motility ratio, \% & $\mathrm{Y}=59.637-0.032$ age+0.504 LW & 10.30 & 0.04 & $0.19 *$ \\
Immotility ratio, \% & $\mathrm{Y}=18.369+0.013$ age-0.237 LW & 6.24 & 0.13 & 0.13 \\
Dead spermatozoa ratio, \% & $\mathrm{Y}=21.849+0.020$ age-0.268 LW & 5.80 & 0.11 & 0.11 \\
\hline
\end{tabular}

*P<0.05, LW: Live Weight 
Phenotypic correlations between reproductive traits in Chios ram lambs are given in Table 6. The correlations between all testis characteristics were found to be significant $(\mathrm{P}<0.01)$. This result is consistent with some studies (Kaymakç1 et al. 1988; Odabaşığlu et al. 1992; Taşkın 1995; Kaya et al. 1999; Karagiannidis et al. 2000; Rege et al. 2000; Y1lmaz \& Aygün 2002; Gündoğan et al. 2003b; Kulaks1z et al. 2010). The ejaculate volume had significant correlations with mass movement $(\mathrm{P}<0.05)$, sperm density $(\mathrm{P}<0.05)$, sperm consistency $(\mathrm{P}<0.01)$, and progressive motility ratio $(\mathrm{P}<0.01)$. The obtained result is similar with some studies (Kaymakçı et al. 1988; Odabaşığlu et al. 1992; Taşkın 1995; Kaya et al. 1999; Karagiannidis et al. 2000; Rege et al. 2000; Gündoğan et al. 2003b; Yılmaz \& Karaca 2004; Y1lmaz 2006; Kulaksız et al. 2010). Whilst there was a positive correlation between testicular diameter, ejaculate volume and progressive motility ratio in mass motility; the relationships between the testicular diameter and scrotal circumference with the dead spermatozoa ratio, and between scrotal circumference and testicular volume with immotility ratio had negative significant ( $\mathrm{P}<0.01)$. Toe et al. (1994) and Al-Kawmani et al. (2018) stated that sperm quality would increase as testis develops. The increase or decrease in the testosterone hormone levels of Chios ram lambs was statistically insignificant. Some researchers mentioned the importance of the features related to the testosterone hormone (Langford et al. 1990; Lincoln et al. 1990; Fernandez et al. 1993; Taşkın 1995; Gündoğan 1999; Aygün \& Karaca 2000; Rege et al. 2000; Gündoğan et al. 2003b), yet others have emphasized that testosterone levels alone were not sufficient in determining the libidos of the rams and could be affected by environmental factors (Dufour et al. 1984). In this study, the positive correlation was determined between the live weight and age of the Chios ram lambs; and there was also a significant positive correlation between testicular diameter, testicular length, testicular volume, scrotal circumference and length with live weight and age $(\mathrm{P}<0.05 ; \mathrm{P}<0.01)$. The live weight and age had significant and negative correlations only with sperm density from sperm characteristics.

Table 6- Correlations between reproduction traits in Chios ram lambs

\begin{tabular}{|c|c|c|c|c|c|c|c|c|c|c|c|c|c|c|}
\hline & $T L$ & $S C$ & $S L$ & $T V$ & $E V$ & $S D$ & $P M R$ & $I M R$ & DSO & $M M$ & $C S$ & $T$ & $L W$ & $A$ \\
\hline $\mathrm{TD}$ & $0.9525 * *$ & $0.9310 * *$ & $0.9067 * *$ & $0.9583 * *$ & 0.3195 & -0.1114 & $0.3669^{* *}$ & -0.1570 & $-0.4900^{* *}$ & $0.3209^{* *}$ & $0.3860^{*}$ & -0.2723 & $0.926 * *$ & $0.916^{* *}$ \\
\hline TL & & $0.9339 * *$ & $0.8899 * *$ & $0.9586 * *$ & -0.0851 & -0.3425 & -0.0280 & -0.0819 & 0.1385 & -0.2810 & -0.1554 & -0.2780 & $0.924 * *$ & $0.908^{* *}$ \\
\hline $\mathrm{SC}$ & & & $0.9117 * *$ & $0.9583 * *$ & 0.2763 & 0.1764 & $0.4255^{* *}$ & $-0.3572 * *$ & $-0.3857^{* *}$ & 0.1805 & $0.4993^{* *}$ & 0.0786 & $0.872 * *$ & $0.827 * *$ \\
\hline SL & & & & $0.9120 * *$ & 0.1150 & -0.0456 & $0.4745^{* *}$ & $-0.4599 * *$ & -0.3673 & 0.3078 & 0.3358 & 0.0720 & $0.866^{*}$ & $0.840 * *$ \\
\hline TV & & & & & 0.1650 & -0.0539 & $0.3170 * *$ & $-0.3202 * *$ & -0.2294 & -0.0129 & $0.3094 * *$ & -0.0985 & $0.925 * *$ & $0.895^{* *}$ \\
\hline EV & & & & & & 0.3797 * & $0.2199 * *$ & -0.1451 & -0.2649 & $0.3084 *$ & $0.4862 * *$ & 0.0394 & -0.1894 & -0.1130 \\
\hline SD & & & & & & & 0.1299 & -0.0966 & -0.1454 & 0.0504 & 0.3098 & -0.0882 & $-0.4906^{* *}$ & $-0.5331 * *$ \\
\hline PMR & & & & & & & & $-0.9290 * *$ & $-0.8643^{* *}$ & $0.7264 * *$ & $0.6293^{* *}$ & 0.0434 & 0.2990 & 0.0792 \\
\hline IMR & & & & & & & & & $0.7117 * *$ & $-0.4740 * *$ & $-0.4924 * *$ & -0.0729 & -0.291 & -0.0278 \\
\hline DSO & & & & & & & & & & $-0.8038^{* *}$ & $-0.6078 * *$ & -0.0026 & -0.3187 & -0.1128 \\
\hline MM & & & & & & & & & & & $0.6559 * *$ & -0.0223 & 0.2627 & 0.0770 \\
\hline $\mathrm{CS}$ & & & & & & & & & & & & 0.0634 & 0.1988 & 0.1691 \\
\hline $\mathrm{T}$ & & & & & & & & & & & & & -0.2304 & -0.3406 \\
\hline LW & & & & & & & & & & & & & & $0.932 * *$ \\
\hline
\end{tabular}

TD; Testicular Diameter TL; Testicular Length, SC; Scrotal Circumference, SL; Scrotal Length, TV; Testicular Volume, EV: Ejaculate Volume, SD; Sperm Density, PMR; Progressive Motility Ratio, IMR; Immotility Ratio, DSO; Dead Spermatozoa Ratio, MM; Mass Movement, CS; Consistency of Sperm, T; Testosterone, LW; Live Weight, A; Age ${ }^{*} \mathrm{P}<0.05,{ }^{* *} \mathrm{P}<0.01$

\section{Conclusions}

In this study, testis, sperm characteristics and testosterone hormone levels of Chios ram lambs were determined from $3^{\text {rd }}$ month to $12^{\text {th }}$ months of age. The effect of live weight and age on these reproductive traits was examined. In spite of the changes in the live weight and age, the changes in these properties are given by regression equations. It is known that testis characteristics of rams differ with breeds and the growth rates of some testis characteristics are different from each other. According to the findings of this study, all testis characteristics can be defined for a specific age and live weight can be determined from the regression equations based on the significant effect of age and live weight. As the testicular diameter and volume, scrotal circumference and length enlarged, the rate of the sperm motility increased. This result can be used to estimate the rate of live spermatozoa of the ram lambs by taking morphological measurements at an early age. 
In conclusions, because of the higher inheritance level of the testis characteristics they can be used as indirect selection criterion. As a result, the degree of success in the selection programs for ram lambs will be increase. This study was the first to examine the relationships among the reproductive characteristics of the Chios sheep breed in Turkey. It will contribute to the future investigations on reproductive studies and these results must be incorporated with genomic studies by several genes related by twins and reproduction.

\section{Acknowledgements}

This research was supported by Ege University Research Fund (2009-ZRF-034).

\section{References}

Aguirre V, Orihuela A \& Vázquez R (2007). Effect of semen collection frequency on seasonal variation in sexual behaviour, testosterone, testicular size and semen characteristics of tropical hair rams. Tropical Animal Health and Production 39(4): 271-277

Ake-Lopez J, Raké-Villanueva N Y, Segura-Correa J C, Ake-Villanueva J R \& Montes-Perez R C (2016). Effect of age and season on semen traits and serving capacity of Pelibuey rams under tropical conditions. Livestock Research for Rural Development 28(9): 166

Aksoy M, Ataman M B, Karaca F \& Kaya A (1994). Interrelationships between morphometric measurements of testes and sperm quality in Merino rams (In Turkish). Eurasian Journal of Veterinary Sciences 10: 127-129

Alexopoulos K, Karagiannidis A \& Tsakalof P (1991). Development of macroscopic and microscopic characteristics of ejaculates from Chios, Serres and Karaguniki breed lambs. Therogenology 36(4): 521-708

Al-Kawmani A, Alfuraiji M M, Kandeal S A, Farah M A \& Alanazi K M (2018). Pubertal changes in testicular parameters and secretion of testosterone in Najdi and Naemi ram lambs under desert conditions. Indian Journal of Animal Research 52(2): 212-219

Aygün T \& Karaca O (1995). Some testicular characteristics in Karakas male lambs (In Turkish). Turkish Journal of Veterinary and Animal Sciences 19: 161-167

Aygün T \& Karaca O (2000). The relationships between serum testosterone concentrations and testis characteristics of Karakas male lambs (In Turkish). Journal of Agricultural Sciences 6(3): 97-101. https://doi.org/10.1501/Tarimbil_0000000976

Courot M \& Ortavant R (1981). Endocrine control of spermatogenesis in the ram. Journal of Reproduction and Fertility Supplement 30:47-60

Cusabio (2011). Sheep testosterone elisa kit. www.cusabio.com (Retrieved, 08.02.2011)

Delgadillo J A, Leboeuf B \& Chemineau U (1991). Decrease in the seasonality of sexual behavior and sperm production in bucks by exposure to short photoperiodic cycles. Theriogenology 36(5): 755-770

Dufour J J, Fahmy M H \& Minvielle F (1984). Seasonal changes in breeding activity, testicular size, testosterone concentration and seminal characteristics in rams with long or short breeding season. Journal of Animal Science 58 (2): 416-422

Düzgüneş O, Eliçin A \& Akman N (1987). Hayvan 1slahı. Ankara Üniversitesi Ziraat Fakültesi. No:1003, Ankara

Fernandez A D, Villages N, Klappenbach A \& Machado A (1993). Effect of age and breed on semen production and sexual activity. Animal Breeding Abstracts 61: 880

Gonzalez R, Poindron P \& Signoret J P (1988). Temporal variation in LH and testosterone responses of rams after the introduction of oestrous females during the breeding season. Journal of Reproduction and Fertility 83: 201-208

Gülyüz F \& Y1ldız C (1995). Investigations on the spermatological characteristics and fertility of various breed rams (In Turkish). The Journal of the Faculty of Veterinary Medicine University of Yuzuncu Yil 6(1-2): 60-63

Gündoğan M (1999). Correlation of the testicle measures between semen characteristics and blood serum testosterone levels of the rams (In Turkish) Journal of Animal Research 9: 49-52

Gündoğan M (2007). Seasonal variation in serum testosterone, T3 and andrological parameters of two Turkish sheep breeds. Small Ruminant Research 67: 312-316

Gündoğan M \& Demirci E (2003). Monthly changes in some reproduction parameters in testosterone and thyroxine values of ram throughout one-year continental climate conditions. Deutsche Tierarztliche Wochenschrift 110: 450-453

Gündoğan M, Demirci E, Bozkurt T \& Sönmez M (1997). The changes before, during and later the breeding season in the semen characteristics of the rams (In Turkish). The Journal of the Faculty of Veterinary Medicine University of Yuzuncu Yil 8(1-2): 40-42

Gündoğan M, Uçar M \& Tekerli M (2002). A study on morphometric measurements of testes and spermatologic features of rams kept under Afyon conditions (In Turkish). Eurasian Journal of Veterinary Sciences 18(1-2): 63-67

Gündoğan M, Uçar M \& Tekerli M (2003a). An investigation on the relationships between the morphometric measurements of testes and other spermatological features in the rams maintained in the conditions of Afyon before, during and after the breeding period (In Turkish). Journal of Lalahan Livestock Research Institute 43(1): 9-22

Gündoğan M, Uçar M, Tekerli M \& Yeni D (2003b). Possible association between age and reproductive parameters in Akkaraman rams during breeding season. Hayvancılık Araştırma Dergisi 13: 1-2

Hassanin S H, Hussein A F, Khattab Y A \& Abdalla M A (2013). Reproductive performance of rams under arid conditions. Life Science Journal 10(4): 2596-2605

İkiz F, Püskülcü H \& Eren Ş (1996). İstatistiğe giriş. Barış Yayınları Fakülteler Kitabevi, İzmir 402-403

İnce D \& Karaca O (2009). Seasonal changes of testis characteristics and semen quality in Karya and Cine Capari rams (In Turkish). Journal of Animal Production 50(2): 9-15

IBM SPSS (2017). Statistics for Windows, Version 25.0. IBM Corporation, Armonk, New York

Ismaeel M A (2018). Seasonal effect on the scrotal circumference, concentration of testosterone and some biochemical parameters in Nuaimie breed rams in Salah-din province. Al-Anbar Journal of Veterinary Science 11(1-7)

JMP (2003). JMP User Guide Version, 5.0.1.2. SAS Institute, Carey, North Carolina

Karaca F, Gülyüz F, Tasal İ \& Demir H (1998). Studies on spermatologic features and measurements of testes in Hamdane rams (In Turkish). The Journal of the Faculty of Veterinary Medicine University of Yuzuncu Yil 9(1-2): 14-16

Karagiannidis A, Varsakeli S, Alexopoulos C \& Amarantidis I (2000). Seasonal variation in semen characteristics of Chios and Friesian rams in Greece. Small Ruminant Research 37: 125-130 
Karakuş K \& Cengiz F (2007). The effect of spermatologic characteristics on fertility in adult Norduz and Karakaş rams (In Turkish). Yuzuncu Yil University Journal of Agricultural Sciences 17(1): 7-15

Kaya A, Yıldız C, Lehimcioğlu N C, Ergin A \& Aksoy M (1999). Seasonal variation in sperm quality, testicular size and plasma testosterone concentrations in Konya Merino rams (In Turkish). Journal of Animal Research 9(1-2): 1-5

Kaymakçı M (2016). İleri koyun yetiştiriciliği kitabı, genişletilmiş 5. Baskı. Meta Basım Matbaacılık, Bornova, İzmir

Kaymakçı M, Sarıcan C \& Karaca O (1988). Investigation of testicular characteristics in male Acıpayam lambs (In Turkish). Journal of Agriculture Faculty of Ege University 25(2): 109-123, İzmir

Kırk K (2001). Morphological and physiological development of testicles in male Awassi lambs (In Turkish). PhD Thesis (Published) Çukurova Üniversitesi Fen Bilimleri Enstitüsü, Adana

Kridli RT \& Al-Yacoub A (2006). Sexual performance of Awassi ram lambs reared in different sex composition groups. Applied Animal Behaviour Science 96: 261-267

Kridli RT \& Said S I (1999). Libido testing and the effect of exposing sexually Naive Awassi rams to estrous ewes on sexual performance. Small Ruminant Research 32: 149-152

Kulaksız R, Daşkın A \& Akçay E (2010). A study on morphometric measurements of testes and spermatologic features of Karayaka rams during nonbreeding season (In Turkish). Veterinary Journal of Ankara University 57: 263-265

Langford G A, Shrestha J N B, Sanford L M \& Marcus G J (1990). Repeatability of scrotal size and semen quality measurements in rams in a short-day light regime. Animal Breeding Abstracts 58: 406

Langford G A, Shrestha J N B, Sanford L M \& Marcus G J (1998). Reproductive hormone levels of early postpubertal ram lambs in relation to breed, adult testis size and semen quality. Small Ruminant Research 29: 225-231

Lincoln G A, Lincoln C E \& McNeilly A S (1990). Seasonal cycles in the blood plasma concentration of FSH, inhibin and testosterone, and testicular size in rams of wild, feral and domesticated breeds of sheep. Journal of Reproduction and Fertility 88: 623-633

Martin L M, Crenshaw C C, Dean J A, Dart M G, Purdy P H \& Ericsson S A (1999). Determination of the number of motilite sperm within an ovine semen sample using resazurin. Small Ruminant Research 32: 161-165

Maxwell W M C (1986). Artificial insemination of ewe with frozen thawed semen at a synchronised oestrus; 1 . Effect of spermatozoa and site of intrauterine insemination on fertility. Animal Reproduction Science 10: 309-316

Minitube (2013). Sperm vision, chemical preparation, http://www.minitube.de (Retrieved 17.01.2013)

Moore C \& Sanford L M (1987). Genetics influence of predictability of testis function in rams. Animal Breeding Abstracts 55: 262

Moraes J C, Oliveria N M \& Ferruguem Moraes J C (1992). Evaluation of Romney rams on the basis testis dimension. Revista Brasileira-de Reproducao Animal 16(1-2): 55-62

Nowakowski P \& Cwikla A (1994). Seasonal variation it testes size in Polish Merino rams and its relationship to reproductive performance in spring. Theriogenology 42: 613-622

Odabaşıŏlu F, Karaca O \& Altın T (1992). Some characteristics of testis in Morkaraman yearling-male lamb and ram (In Turkish). Selçuk Üniversitesi Ziraat Faktültesi Dergisi 8(1): 32-33

Özdemir Z \& Altın T (2002). Some testis characteristics in Kıvırcık male lambs (In Turkish). Yuzuncu Yil University Journal of Agricultural Sciences 12(1): 13-20

Öztürkler Y, Ak K \& İleri İ K (1997). The effect of season on post thaw spermatological properties in Kivırcık rams (In Turkish). Kafkas Üniversitesi Veteriner Fakültesi Dergisi 3(1): 73-79

Price E O, Bench C J, Borgwardt R E \& Dally M R (2000). Sexual performance of twin ram lambs and the effect of number and sex of contemporary siblings. Applied Animal Behaviour Science 68: 199-205

Rege J E O, Toe F, Mukasa-Mugerwa E, Tembely S, Anindo D, Baker R L \& Lahlou-Kassi A (2000). Reproductive characteristics of Ethiopian Highland sheep, II. genetic parameters of semen characteristics and their relationships with testicular measurements in ram lambs. Small Ruminant Research 37: 173-187

Salhaba S A, Zarkawib M, Wardehc M F, Al-Masrib M R \& Kassemd R (2001). Development of testicular dimensions and size, and their relationship to age, body weight and parental size in growing Awassi ram lambs. Small Ruminant Research 40: 187-191

Salhaba S A, Zarkawib M, Wardehc M F, Al-Masrib M R \& Kassemd R (2003). Characterization and evaluation of semen in growing Awassi ram lambs. Tropical Animal Health and Production 35: 455-563

Souza C E A, Arau'Jo1 A A, Oliveira J T A, Lima Souza A C, Neiva J N M \& Moura A A (2010). Reproductive development of Santa Ine^s rams during the first year of life: body and testis growth, testosterone concentrations, sperm parameters, age at puberty and seminal plasma proteins. Reproduction in Domestic Animals 45: 644-653

Soylu M K, Gökçen H, Tümen H \& Dogan İ (1991). Studies on some andrological features of imported rams in different breeds (In Turkish). Hayvancilık Araştırma Dergisi 1(1): 15-18

Sönmez M \& Demirci E (2003). The effect of intramuscular vitamin C applications on semen quality in rams (In Turkish). Firat University Veterinary Journal of Health Sciences 17(3): 195-201

IBM SPSS (2017). Statistics for Windows, Version 25.0. IBM Corporation, Armonk, New York

Taha T A, Abdel-Gawad E I \& Ayoub M A (2000). Monthly variations in some reproductive parameters of Barki and Awassi rams throughout 1 year under suptropical conditions, 1. semen characteristics and hormonal levels. Journal of Animal Science 71(2): 317-324

Taşkın T (1995). Seasonal variation of some breeding traits in Kıvırcık and Dağlıç male lambs (In Turkish). PhD Thesis (Published) Ege Üniversitesi Fen Bilimleri Enstitüüsü, İzmir

Taşkın T \& Kaymakçı M (1996). Changes in some reproductive traits in Kıvırcık and Dağlıç male lambs (In Turkish). Journal of Agriculture Faculty of Ege University 33(2-3): 73-81

Tekin N (1990). Erkek üreme organlarının muayenesi (androlojik muayeneler). (Ed: E Alaçam) Theriogenology, Nurol Matbaacılık A.Ş., Ankara s. 53- 67

Tietz N W (1987). Fundamentals of clinical chemistry, $3^{\text {rd }}$ edition. WB Saunders Company, Philadelphia 944-975

Toe F, Lahlon-Kassi A \& Mukasa-Mugerwa E (1994). Semen characteristics of Ile-De-France rams of different age and physical conditions. Theriogenology 42: 321-326

Toe F, Rege J E O, Mukasa-Mugerwa E, Tembely S, Anindo D, Baker R L \& Lahlou-Kassi A (2000). Reproductive characteristics of Ethiopian highland sheep I. Genetic parameters of testicular measurements in ram lambs and relationship with age at puberty in ewe lambs. Small Ruminant Research 36: 227-240

Tsakmakidis I A (2010). Ram semen evaluation: Development and efficiency of modern techniques. Small Ruminant Research. 92 : 126-130 
Wilson J D (1999). The role of anrogens in male gender role behaviour. Biology Reproduction 60: 1373-1377

Yılmaz A \& Aygün T (2002). Some testis characteristics of Norduz male lambs (In Turkish). Yuzuncu Yil University Journal of Agricultural Sciences 1(12): 21-26

Y1lmaz A \& Cengiz F (2010). The some spermatological characteristics in Norduz ram lambs and its change based on age (In Turkish). Yuzuncu Yil University Journal of Agricultural Sciences 20(2): 52-57

Yılmaz B (1999). Hormonlar ve üreme fizyolojisi. 1. Basım, Feryal Matbaacılık, Ankara

Y1lmaz O \& Karaca O (2004). Seasonal changes in sperm characteristics of Chios and Karya type rams (In Turkish). 4. Ulusal Zootekni Bilim Kongresi. Bildiriler: 1-3 Eylül, Isparta pp. 130-135

Zamiria M J, Khalili BB, Jafaroghli C M \& Farshadd A (2010). Seasonal variation in seminal parameters, testicular size, and plasma testosterone concentration in Iranian Moghani rams. Small Ruminant Research 94: 132-136 